Images in...

\title{
Chronic cavitating pulmonary aspergillosis with lung abscess
}

\author{
Kathryn Musgrave, Laura Succony, Reena Kotecha
}

Department of Medicine, The Lister Hospital, Stevenage, UK

Correspondence to Dr Kathryn Musgrave, kathrynmusgrave@gmail.com; kathrynpullman@gmail.com

\section{DESCRIPTION}

This is a case of chronic cavitating pulmonary aspergillosis complicated by bacterial infection in a 71-year-old gentleman. He had a history of chronic obstructive pulmonary disease (COPD; severe, Forced expiratory volume in $1 \mathrm{~s}=0.94)$ and was treated with Seretide and Tiotropium. Prior to this illness he had a good functional status. He presented with a 1-month history of progressive shortness of breath. Chest radiograph showed a large welldemarcated cavity in the left upper zone (figure 1). Further investigation by CT showed a large $10 \times 10 \mathrm{~cm}$ cavitating lesion in the left upper lobe (figure 2). Bronchoscopy and bronchoalveolar lavage were performed and Aspergillus fumigans cultured. He had a positive Aspergillus precipitans with a titre of 1 in 16. Cultures for acid fast bacilli were negative (figure 3 ).

He was successfully treated with a combination of antifungals and antibiotics. The treatment included 13 days of Fungizone $50 \mathrm{mg}$ daily with Piperacillin/Tazobactam

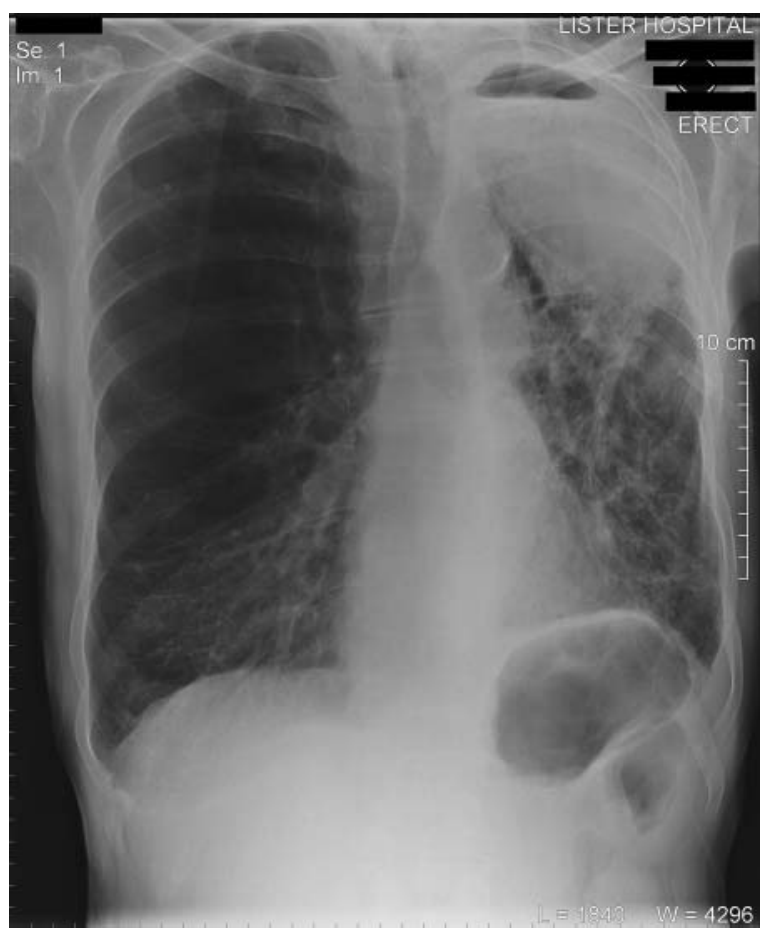

Figure 1 Presenting chest radiograph showing a large fluid-filled cavity in left upper lobe. The lungs are overinflated with emphysematous change in both lung fields.

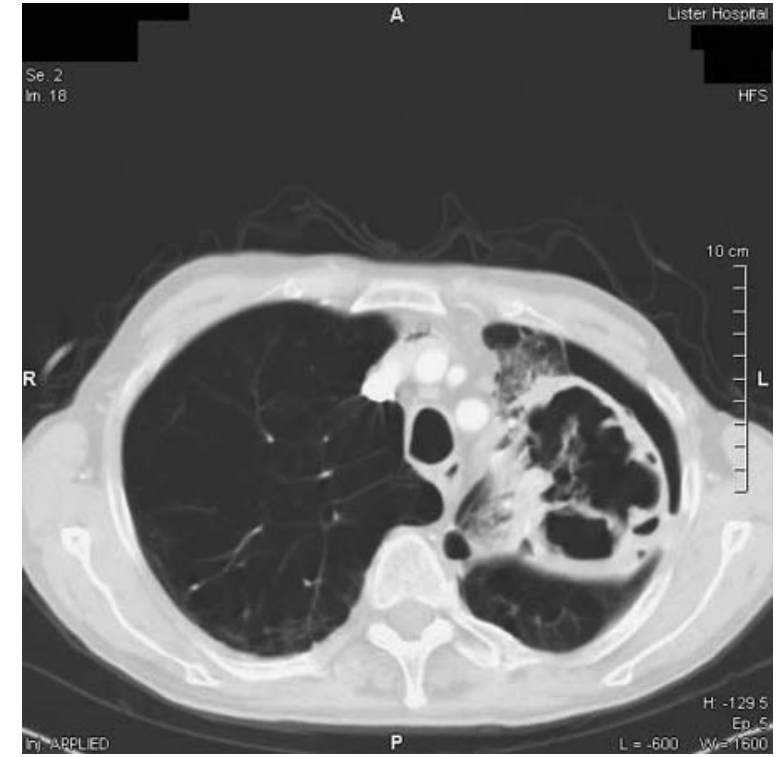

Figure 2 Presenting thorax CT. Demonstrates a cavitating lesion on the left side of the chest measuring $10 \times 10 \mathrm{~cm}$ with a thick, irregular wall and internal septations. There was a further smaller lesion in the left lower lobe of $1.2 \mathrm{~cm}$. Supero-laterally to the larger lesion there is a small associated pneumothorax. Note also the general emphysematous change.

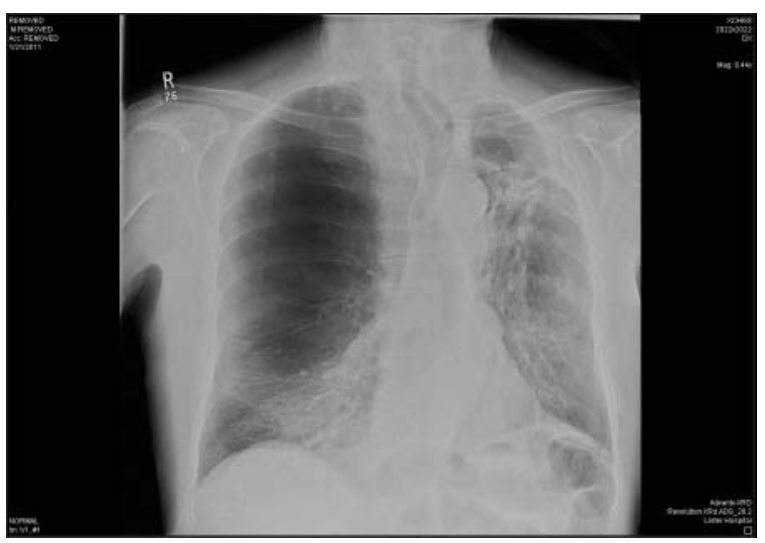

Figure 3 Post-treatment chest radiograph showing persistent cavity. Emphysematous changes in the right upper lobe and fibrotic scarring in the left upper zone. 


\section{BMJ Case Reports}

initially. There was no clinical improvement and this was changed following microbiological advice to Ambisome $150 \mathrm{mg}$ daily and Meropenem of which he received 22 days in total. Colomycin nebulisers and oral Itraconazole were then started and continued on discharge for 3 months. Treatment duration was guided by clinical recovery and C-reactive protein levels. Two years later, he remains clinically well under outpatient review. A recent chest radiograph demonstrates marked improvement.

COPD is now a recognised risk factor for chronic aspergillosis, and the diagnosis should be considered in all patients who present with an indolent history, previous pulmonary disease and a pulmonary cavity on chest radiograph. ${ }^{1-3}$

\section{Competing interests None.}

Patient consent Obtained.

\section{REFERENCES}

1. Denning DW, Smith NL. Underlying conditions in chronic pulmonary aspergillosis, including simple aspergilloma. Eur Respir J 2010;37:865-72.

2. Denning DW, Riniotis K, Dobrashian R, et al. Chronic cavitary and fibrosing pulmonary and pleural aspergillosis: case series, proposed nomenclature and review. Clin Infect Dis 2003;37(Suppl 3):S265-80.

3. Camuset J, Nunes H, Dombret MC, et al. Treatment of chronic pulmonary aspergillosis by voriconazole in nonimmunocompromised patients. Chest 2007;131:1435-41

This pdf has been created automatically from the final edited text and images.

Copyright 2012 BMJ Publishing Group. All rights reserved. For permission to reuse any of this content visit http://group.bmj.com/group/rights-licensing/permissions.

BMJ Case Report Fellows may re-use this article for personal use and teaching without any further permission.

Please cite this article as follows (you will need to access the article online to obtain the date of publication).

Musgrave K, Succony L, Kotecha R. Chronic cavitating pulmonary aspergillosis with lung abscess. BMJ Case Reports 2012; 10.1136/bcr-03-2012-6018, Published XXX

Become a Fellow of BMJ Case Reports today and you can:

- Submit as many cases as you like

- Enjoy fast sympathetic peer review and rapid publication of accepted articles

- Access all the published articles

- Re-use any of the published material for personal use and teaching without further permission

For information on Institutional Fellowships contact consortiasales@bmjgroup.com

Visit casereports.bmj.com for more articles like this and to become a Fellow 